University of Nebraska - Lincoln

DigitalCommons@University of Nebraska - Lincoln

September 2003

\title{
Replacement Names for the Genera Batesiana Erwin (Coleoptera: Carabidae) and Metabolus Fairmaire (Coleoptera: Scarabaeidae: Melolonthinae)
}

\author{
M. J. Paulsen \\ University of Nebraska-Lincoln, mjpaulsen@unl.edu \\ Andrew Smith \\ asmith@unl.edu
}

Follow this and additional works at: https://digitalcommons.unl.edu/entomologypapers

Part of the Entomology Commons

Paulsen, M. J. and Smith, Andrew, "Replacement Names for the Genera Batesiana Erwin (Coleoptera: Carabidae) and Metabolus Fairmaire (Coleoptera: Scarabaeidae: Melolonthinae)" (2003). Papers in Entomology. 16.

https://digitalcommons.unl.edu/entomologypapers/16

This Article is brought to you for free and open access by the Museum, University of Nebraska State at DigitalCommons@University of Nebraska - Lincoln. It has been accepted for inclusion in Papers in Entomology by an authorized administrator of DigitalCommons@University of Nebraska - Lincoln. 


\title{
SCIENTIFIC NOTE
}

\author{
Replacement Names for the Genera Batesiana Erwin (Coleoptera: Carabidae) and \\ Metabolus Fairmaire (Coleoptera: Scarabaeidae: Melolonthinae)
}

While curating scarab beetles in the University of Nebraska State Museum collection, we discovered two generic names that are homonyms. As this renders these names invalid, we herein propose replacement names for the junior homonyms as follows.

\section{Erwiniana Paulsen and Smith new genus}

=Batesiana Erwin, 1994:581.

Batesiana Erwin, 1994 (Coleoptera: Carabidae: Bembidiini) is a junior homonym of Batesiana Chalumeau, 1983 (Coleoptera: Scarabaeidae: Aphodiinae). We propose Erwiniana new genus as a replacement name and an objective synonym of Batesiana Erwin as delineated in Articles 60.3 and 72.7 of the International Code of Zoological Nomenclature (1999). The name Erwiniana (gender feminine) honors Terry L. Erwin (Smithsonian Institution, Washington, D.C. U.S.A.) who described many of the 57 currently recognized species in the genus. The type species of Batesiana (Xystostomus gruti Bates by original designation) automatically becomes the type species of Erwiniana. The species of Batesiana listed in Erwin (1994) are thus placed in a new combination with the valid name Erwiniana.

Ablotemus Paulsen and Smith new genus

=Metabolus Fairmaire, 1887:107.

Metabolus Fairmaire, 1887 (Coleoptera: Scarabaeidae: Melolonthinae) is a junior homonym of Metabolus Bonaparte, 1854 (Aves: Passeriformes: Monarchidae). We propose the name Ablotemus new genus as a replacement name and an objective synonym of Metabolus Fairmaire. The etymology of the name Metabolus (gender masculine) remains unclear, thus we have chosen the replacement name Ablotemus (gender masculine), an anagram of the original generic name. The type species of Metabolus (M. tumidifrons Fairmaire by monotypy) automatically becomes the type species of Ablotemus. The species currently considered to be in the genus Metabolus are hereby transferred to the genus Ablotemus.

This publication was supported by NSF/PEET grants DEB-9712447 to B. C. Ratcliffe and Mary Liz Jameson and DEB-0118669 to M. L. Jameson and B. C. Ratcliffe.

\section{Literature Cited}

Bonaparte, L. 1854. Notes sur les collections rapportées en 1853, par M. A. Delattre, de son voyage en Californie et dans le Nicaragua. Comptes Rendus Hebdomaire des Seances de l'Academie des Sciences 38:650-665.

Chalumeau, F. 1983. Batesiana et Martinezia, nouveaux genres d'Eupariini (Coleoptera: Scarabaeidae: Aphodiinae) du nouveau monde. Bulletin Mensuel de la Société Linnéenne de Lyon 52:142-153.

Erwin, T. L. 1994. Arboreal beetles of tropical forests: the Xystosomi group, subtribe Xystosomina (Coleoptera: Carabidae: Bembidiini). Part I. Character analysis, taxonomy, and distribution. Canadian Entomologist 126:549-666.

Fairmaire, L. 1887. Coléoptères de l'intérieur de la Chine. Annales de la Société Entomologique de Belgique 31:107-136.

International Commission on Zoological Nomenclature. 1999. International Code of Zoological Nomenclature, Fourth Edition. International Commission on Zoological Nomenclature, The Natural History Museum, London. 306 pp.

M. J. Paulsen and Andrew B. T. Smith, Division of Entomology, University of Nebraska State Museum,Lincoln, NE68588-0514,U.S.A.E-mails: mpaulsen@unlserve.unl.edu, asmith@ unlserve.unl.edu

(Received 19 November 2002; accepted 19 December 2002. Publication date 12 September 2003.) 